\title{
Current Situation Analysis and Countermeasure Research of Party History Study and Education of College Students in the New Era —-Based on a Survey of College Students in Sichuan Province
}

\author{
Yang Long, ${ }^{1, a}$, Yang Fan ${ }^{2, *}$ \\ ${ }^{1}$ Business School, Chengdu University, Chengdu, China \\ ${ }^{2}$ Social Science Department, Chengdu University, Chendgu, China \\ ayanglong@cdu.edu.cn \\ *Corresponding author. Email: yangfan@cdu.edu.cn
}

\begin{abstract}
A history of the development of the Chinese Communist Party is also a history of the Chinese Communist Party's own construction and the history of party history learning, education and exploration. Based on the questionnaire survey and interview with some college students in Sichuan province, this paper analyzes the implementation of party history education among college students, educational results and existing problems. This paper puts forward some countermeasures and suggestions, such as following the overall requirements and general rules of party history study and education, basing on the reality of young people, guiding young students to set up correct party history view, making good use of the main channel of classroom teaching, innovating educational methods, and making party history study and education "come alive".
\end{abstract}

Keywords: College students, Party history study and education, Present situation and Countermeasures.

\section{INTRODUCTION}

On July 1, 2021, on the historic occasion of the 100th anniversary of the founding of the Communist Party of China (CPC), Chinese President Xi Jinping declared to the world from the gate tower over Tiananmen Square, "By learning from history, we can understand why powers rise and fall. Through the mirror of history, we can find where we currently stand and gain foresight into the future. Looking back on the Party's 100-year history, we can see why we were successful in the past and how we can continue to succeed in the future. This will ensure that we act with greater resolve and purpose in staying true to our founding mission and pursuing a better future on the new journey that lies before us."[1] The Communist Party of China (CPC) on Feb 20 launched a campaign on Party history learning and education among all of its members. Speaking at the campaign's launch meeting, President Xi Jinping called for efforts to promote the history of the Chinese revolution is the best nourishment. Relive this great history can be vividly educated by the party's original mission, nature, purpose, ideals and beliefs. Remember the glorious history and inherit the red gene.[2]

"History is the best textbook". "Learning the history of the party and the country is a compulsory course for us to uphold and develop socialism with Chinese characteristics and to continue to advance the various undertakings of the party and the country". "This homework is not only required, but it must be completed." As General Secretary Xi Jinping has said that we should do a good job in the study and education of young people, focus on telling stories of the party, revolutions, and heroes, and cultivate the love of the party, the country, and the love of socialism, so that the red gene and the revolution will be replaced. Inheritance from generation to generation.[3] General secretary Xi Jinping pointed, we must do a good job in the study and education of young people, focus on telling the stories of the Party, the revolution, and the heroes, and cultivate the love of the Party, the country, and the love of socialism, so that the red gene and the revolution can be passed on from generation to generation.[4] The Hope 
of the country lies in the youth. The future of the nation lies in the youth. Youths are the most active and energetic power in the entire social force. Youths shoulder the sacred mission of building a modern and powerful socialist country in an all-round way and realizing the Chinese dream of the great rejuvenation of the Chinese nation. Actively grasp the youth group, carry out various forms of education on the party's historical knowledge, glorious traditions and fine styles, heroes and deeds, and guide young students to vigorously carry forward the red tradition and inherit the red gene, and continue the spiritual blood of the Communists, having the "two overall situations" in mind, being good at analyzing and grasping historical trends, summarizing historical experience, grasping historical laws, and enhancing the courage and strength to advance forward is of great strategic significance.[5]

In order to understand the implementation of party history study and education among college students in Sichuan province, education results and existing problems. From October 15 to November 15, 2021, the research team selected 12 universities, including Sichuan University, Southwest Jiaotong University, Chengdu University, Yibin University and Chengdu Polytechnic Institute as the research objects to conduct questionnaire survey and interview. 1800 questionnaires were sent out online and 1657 were effectively received with effective recovery of $92.06 \%$. This survey has a wide range and a large number of participants, which can better present the basic current situation of party history education implementation among college students in Sichuan Province. The research group used SPSS21.0 software for statistical analysis of the questionnaire results, summarized the achievements and shortcomings of party history learning education of college students in Sichuan Province, and put forward the corresponding countermeasures, in order to provide useful reference for the new era of party history learning education of college students.

\section{THE CURRENT SITUATION AND PROBLEMS OF COLLEGE STUDENTS' PARTY HISTORY STUDY AND EDUCATION}

\subsection{The binary deficit between mainstream promotion and passive reception expands.}

General Secretary Xi Jinping stressed at the Party history Study and Education Mobilization Meeting: "To carry out Party history study and education throughout the Party is a necessary requirement to keep in mind our original mission and advance the historic cause of the great rejuvenation of the Chinese nation. It is a necessary requirement for strengthening our faith and belief and upholding and developing socialism with Chinese characteristics in the new era. It is a necessary requirement for promoting the Party's self-revolution and maintaining the Party's vitality forever". "The whole Party must attach great importance to it, raise its ideological position, base itself on reality, uphold integrity and make innovations, and fulfill all tasks of learning and education with high standards and high quality."[3] The research group found in the survey that $76.80 \%$ of college students think that their colleges or departments regularly carry out learning education and its content is relatively rich, and $54.12 \%$ of them think that their classes or societies regularly carry out learning education and its content is relatively rich. In addition, $63.25 \%$ of the college students think that the colleges or departments have carried out distinctive and diversified learning education. More than 50\% of the students spoke highly of the solid and effective learning and education organized by their colleges or departments. It can be seen that all the colleges and universities resolutely implement the decisions and arrangements of the CPC Central Committee, and are able to transform their learning results into motivation for serving the people with vigorous spirit and solid and effective work actions.

However, $46.72 \%$ of the students think that with the deepening of learning and education, the actual effect is not obvious, compared with the emphasis and mainstream promotion of colleges and universities. The main performance is that first, ideological and political class is the main position to develop party history education, which is of great significance to the growth of college students. As for the overall evaluation of these courses, some college students think that "the content is monotonous, not vivid enough, not attractive", and some students think that "the professional is too strong, they can't understand". Secondly, some college students still follow the traditional learning concept, and the party history learning and education mostly rely on teachers' teaching, practical activities, lectures and reports. But others, such as network self-study and so on, their initiative to carry out learning enthusiasm, initiative and creativity is not enough. In addition, some college students face the dual pressure of postgraduate entrance examination and employment, most of the time and energy for exam-oriented education knowledge learning, time allocated to the study of party history is relatively less. For a long time, college students are less and less interested in party history education.

\subsection{The contradiction between the maximization of instrumental rationality and value rationality.}

Instrumental rationality originated from the concept of "rationality" put forward by German sociologist Marx Weber. There are two types of rationality, namely value rationality and instrumental rationality. Value rationality emphasizes the purity of motivation and the 
correctness of means, while instrumental rationality emphasizes the purposefulness of results and the maximization of effects, while ignoring emotional and spiritual values. The research team found that $77.65 \%$ of the students thought that the party history learning and education were "very important, very necessary" and "important, very necessary". Publicity and education, news reports, party history research, practical activities and other tasks are also "indispensable". It can be seen that most students have subjectively realized the importance, necessity and urgency of learning and education the party history. However, the importance, necessity and urgency of most students' learning and education the party history only stay on the cognitive level, and have not put actual actions into practice. More than $35.00 \%$ of the students reported that the party history learning and education organized by their university or department largely relied on the daily and regular ideological and political teaching. Some ideological and political theory teachers only use textbooks to carry out teaching, and regard textbooks as the only teaching materials for the party history learning and education.

In the view of Professor Lu Jie, a well-known moral education scholar in our country. She once said that what education expects is not only those who strive to surpass the living conditions in reality and strive to create a better life in practical activities, but also those who constantly explore the value, significance, ideal and purpose of human existence in their thoughts and consciousness and seek for spiritual and ideological transcendence.[3] The party history learning and education is different from descriptive knowledge education, which can achieve the purpose of mastering knowledge by means of one-way communication. As a kind of value learning education, it needs a process of cognition, analysis and acceptance. Party history is the educational material and content of the party history learning and education. Tool rationality helps young people to correctly view history and party history, but ignores that its purpose is to guide the public, especially from the real emotional world and ideological world of students. To guide young students to understand the extraordinary roads that the Chinese people have taken in modern times, to inspire their patriotism and serve the country, instead of just mechanical recitation of party history knowledge or the appearance the dilemma of "it's more important to say than to do" and "value of knowledge over value".

\subsection{The tension contradiction between active networking and pan-entertainment.}

As General Secretary Xi Jinping has pointed out, "If political work cannot pass the threshold of the Internet, it cannot pass the threshold of The Times." At present, the Internet is changing the behavior habits and thinking mode of contemporary college students. Internet has become the forefront of ideological and political education in colleges and universities. Then, how to enhance the effectiveness of party history study and education under the development trend of new media integration featuring fast information transmission, multiple contents and short reception time? Group found in the investigation and research, on college students learning education form in the history of the party, everyone to "party history symposium", "to visit the party history memorial hall" anticipation is higher, but more than $80.00 \%$ of students choose to pass "We Chat, weibo, new media, such as the station B' trill" study for party history education can assign, looking forward to really make learning education "alive". In addition, more than $50 \%$ of the college students said that although colleges or departments are also opening up a new position of learning and education "on the cloud" and actively building a big pattern of "thinking and politics on the cloud", they are unable to get close to the reality of college students, achieve emotional belonging, and fail to make the party history learning and education become deep, warm, connotation and feelings.

The open network environment accelerates the wide spread of various social trends of thought. Foreign network media with ulterior motives took the opportunity to confuse the public. Some maliciously attacked the Communist Party of China through demonization. Some exaggerate historical nihilism, completely deny the history of the Communist Party of China. Some seize and magnify some mistakes in the history of exploration, damage the image of the CPC. In the study and education of party history, there are various phenomena, such as substituting one-sidedness for comprehensiveness, deconstruction for integration, concealing essence with appearance, peddling absurdity with jest, and entailing private goods with interpretation, which have seriously affected people's cognition of historical facts and dispelled social consensus. At the same time, a small number of college students reflect that in some film and television works, there is the party history vulgarization, entertainment, "joking", "spoof", not in line with the history and logic of the plot and bridge. College students' thoughts are not mature, easy to be affected by it, resulting in ideological confusion. For a long time, it will cause irreversible loss and damage to the party and the country.

\section{STRENGTHEN AND IMPROVE THE UNIVERSITY STUDENT PARTY HISTORY LEARNING AND EDUCATION COUNTERMEASURE}

\subsection{Guide Students to adopt a rational outlook on the Party's history}

General secretary $\mathrm{Xi}$ Jinping pointed out that a 
review of the Party's major achievements and historical experience over the past century is necessary for the following purposes, we must adhere to the methodology of dialectical materialism and historical materialism, and treat the party's history from a specific historical, objective, comprehensive, and developmental viewpoint. Adhere to a correct view of party history, establish a big view of history, and accurately grasp the main theme and mainstream nature of the party's historical development. As he has said that we should take a clearcut stand against historical nihilism...... History is the reality of the past, and reality is the history of the future. History, reality and the future are interlinked. Only by correctly understanding history can we better open up the future. To strengthen the study and education of party history among college students in the new era, it is necessary to guide young students to look at party history comprehensively, systematically, and dialectical -ly. Neither avoids mistakes and twists because of achievements, nor denies achievements because of mistakes and twists in exploration. It is necessary to guide young students to take a clear-cut stand to oppose, to refute those who exaggerate the mistakes and twists of the party's history, wantonly smear and distort the party's history, attack the party's leadership, deliberately link party history incidents with real issues, malicious hype, and vulgarize party history. Entertaining, keen to spread gossip anecdotes, talk about illegal overseas publications, "joking" and "spoofing" heroes and models, and even make so-called reevaluation and historical reversal of the traitors and traitors who have long been concluded. It is necessary to guide young students to deeply realize that the leadership of the Communist Party of China is the choice of history and the people in the thrilling historical changes and the magnificent historical picture, and truly understand why the Communist Party of China "can", why Marxism "works" and why socialism with Chinese characteristics is "good". To scientifically grasp the leadership of the CPC is the most essential feature of socialism with Chinese characteristics, as well as the greatest political advantage of socialism with Chinese characteristics, so as to wholeheartedly support the leadership of the CPC and strengthen the conviction and determination to always listen to and follow the Party.[6]

\subsection{Make full use of the main channel of classroom teaching.}

Marx has said, "Theory as long as thorough, can persuade people." Marxist theory is a thorough theory. To strengthen the party history study and education of college students in the new era, we must make good use of the main channel of classroom teaching. First of all, to increase the proportion of the history of the Party, the history of the Chinese revolution, the history of new China, the history of reform and opening up in the compulsory courses of ideological and political theory. Combine the education of party history with the education of patriotism, ideals and beliefs, and the education of revolutionary tradition. Through vivid, indepth, specific horizontal and horizontal comparison, explain some truths clearly, explain clearly, enhance college students' systematic and three-dimensional cognition of the Communist Party of China, stimulate the enthusiasm of young students to learn the history of the Party, and actively construct the correct view of the history of the Party. Thus further establish "listen to the party, go with the party" firm belief. Secondly, in the course of ideological and political teaching, actively explore the integration of various teaching methods, the combination of various teaching methods. Such as case teaching, inquiry teaching, experiential teaching, interactive teaching, mass teaching and so on, to achieve the study of party history and curriculum ideological and political "close" contact. It is to organically integrate party history knowledge and party history figures into disciplinary and professional teaching cases, and fully stimulate the value identification and emotional resonance of college students with the love of the Party, the national conditions and the aspirations of the famous experts and scholars in the subject field. Thirdly, in all kinds of party schools, youth league schools and other training courses held lectures, good at using small stories to refract the main truth, with small people to observe the spirit, from a figure in the historical events, a declaration, or even a small object to spread the party history story inserted in the spread of wings. We should guide aspiring young people to draw closer to Party organizations and learn from revolutionary predecessors and advanced figures. We will further strengthen our ideals and beliefs, enhance our ideological understanding, Party spirit and moral standards, and play a leading and exemplary role in practice.

\subsection{Innovating educational Methods to Make Party History Study and Education "Alive".}

We should give full play to the role of the school's main position, while making good use of the main channel of classroom teaching, we should also innovate the way of party history study and education, and develop the "second classroom". Firstly, we should make full use of thematic class meetings, thematic party day, thematic education activities, but also regularly carry out "see", "listen", "learn", "do", "research" and other practical activities. But also with "write", "painting", "take", "record" and other ways to record the activity process and experience, really let the history of party learning education "hot up, live up, real up". This can strengthen the ideological and emotional feelings of college students who love the party, patriotism and socialism, broaden the breadth of college students' learning education, enhance the depth of 
learning education and improve the participation rate of learning education. Secondly, we need to rely on major anniversaries, important times and important historical events to carry out education. In "July 1" the party's birthday, "August 1" army day, anniversary of the victory of Anti-Japanese War, martyrs memorial day, the national symbol of day and other important nodes, we should take advantage of campus publicity boards, window banner, television, network, newspapers: columns, such as a carrier for launch project, build the strong atmosphere of party history study education, arouse the students' empathy.[7-8] Thirdly, we should give full play to the unique role of new media, so that party history materials and party history stories are electronic, intelligent and visualized. We need to realize the sharing of party history information resources, flexible reproduction of party history stories and multiple sharing of party history experience through the form of multi-perspective, all-round, illustrated, full and vivid data. We need to follow the communication rules of collective memory, remodeling and group emotional infection to create excellent works that keep up with The Times and move people's hearts, especially in the form of live-action shooting, historical images, film clips, cartoons and cartoons to develop online products for party history study and education. To create a "Party history course" that college students love and want to learn, so that the study and education of Party history can be more vivid, vivid and youthful.

\section{CONCLUSION}

At the party history study and education mobilization conference, General secretary Xi Jinping stressed that looking back on the past road of struggle and looking at the road ahead, we must study and summarize the party's history well, and carry on and carry forward the party's successful experience.[2] At the time of celebrating the centenary of our party and the in-depth development of party history learning and education by the whole party, it is a good opportunity and the right time to do a good job in party history learning and education for college students in the new era. The majority of young students must remain modest and prudent, guard against arrogance and rashness, and work hard. We must not be intimidated by any risks or led astray by any distractions, and we must be absolutely certain that we make no catastrophic mistakes on fundamental issues. With the determination to inherit the red gene well, carry forward the revolutionary spirit well, firm ideals and beliefs in learning, thinking and practicing, and fulfill their original mission while working hard with conscientious -ly study, experience and comprehend the CPC's century -old struggle through various channels and carry forward the revolutionary spirit.

\section{ACKNOWLEDGMENTS}

Thanks for the funding of "Ideological and Political Education Research Project of Sichuan Education Department and Training Center of Ideological and Political Work Team in Colleges (Southwest Jiaotong University) (Special project for College counselors) (CJSFZ21-77)" and "2021 Chengdu University 'Curriculum Ideological and Political Education Special Research Project'(2020KC-SZA04)”.

\section{REFERENCES}

[1] Xi JP. The Speech at the Educational Summary Conference on the Theme of "Don't Forget the Original Ideals and Aspirations and Keep the Mission in Mind", 2020-01-09 ( 2 ). http://www.gov.cn/xinwen/2020-01/08/content_ 5467591.htm

[2] Xi JP. The Speech at the Mobilization Conference of Party History Study and Education, 2021. PP. 417. DOI: 10.16634/j.cnki.cn23-1001/d.2021.07.003.

[3] Chen SY. Etc. Theoretical Innovation: A Powerful Ideological Weapon for a Century of Glory of The Communist Party of China.2021, pp.19-27. DOI: 1009-2447 (2022) 01-0019-09.

[4] Liu ZH. The Political Consciousness, Spiritual Character and Logical Path of the Evolution of the Learning View of Chinese Communists over the Past 100 Years, 2021, PP. 24-34. DOI: 1000-260X(2021)06-0024-11.

[5] Sun MD. Etc. The Predicaments and Countermeas -ures of Party History Education for College Students. 2021, pp.5-9. DOI:1671-4806(2021)050005-05.

[6] Zhang ZW. Some Thoughts on Strengthening the Education of Party History for College Students, 2015, pp. 76-79. DOI:10.16075/j.cnki.cn31-1220/ g4.2015.07.016.

[7] Wang ZR. Etc. On Strengthening the Education of Party History for College Students in the New Period, 2012, PP.59-63. DOI: 1002-4409 (2012) 01-0059-05.

[8] Zhang C. Education about History of the Communist Party of China: An Important Mission of Ideological and Political Courses, 2021, pp. 1-5. DOI: 10.16826/j.cnki.1009-7228.2021.02.001. 